\title{
Myocardial extracellular volume fraction (ECV) measurements based on T1-mapping in healthy monozygotic twins - another similarity or rather disagreement in twins?
}

Anca R Florian ${ }^{1 *}$, Anna Ludwig ${ }^{2}$, Sabine Rösch² ${ }^{2}$ Elke Schaeffeler ${ }^{3}$, Matthias Schwab ${ }^{3}$, Udo Sechtem², Ali Yilmaz ${ }^{1}$

From 18th Annual SCMR Scientific Sessions

Nice, France. 4-7 February 2015

\section{Background}

The T1-mapping MOLLI technique has already proved to be a robust and reproducible technique for myocardial extracellular volume fraction (ECV) estimation in both healthy individuals and patients with different cardiomyopathies. Monozygotic twins share the same DNA information and frequently grow up in a similar environment. However, epigenetic as well as environmental factors may lead to major differences in clinical phenotype, organ function as well as character and behaviour. Therefore, monozygotic twins provide a very interesting and attractive research model regarding specific organ structure, metabolism and function.

With this study, we aimed at evaluating possible ECV measurement variations within pairs of healthy monozygotic twins.

\section{Methods}

Fourteen pairs of healthy monozygotic twins $(\mathrm{N}=28$; $21 \%$ male; mean age $25 \pm 5$ years) underwent cardiovascular magnetic resonance (CMR) studies including pre- and post-contrast T1-mapping (MOLLI) and late-gadoliniumenhancement (LGE)-imaging at a 1.5-T scanner (Siemens Aera). Global ECV was calculated for each participant in a mid-ventricular short axis slice. The twins from each pair were assigned randomly to one of two following groups: TWINS A and B. In order to assess variability of ECV measurements, global ECV was measured a second time in TWINS A. Delta ECV was calculated between TWINS in each pair (Delta TWINS) and between the initial and the second measurement in TWINS A (Delta Variability). The respective analyses were performed blinded.

\section{Results}

Mean LV end-diastolic volume was $143 \pm 35 \mathrm{~mL}$ and ejection fraction was $63 \pm 6 \%$. No significant differences in LV volumes, mass and ejection fraction were noted between TWINS A and B. None of the TWINS exhibited any presence of LGE. Mean global ECV was $27 \pm 3 \%$. In the paired analysis, there was no significant difference in global ECV between TWINS A and B $(27 \pm 3 \%$ vs. $27 \pm 3 \%, p=0.26)$ or between the two measurements in TWINS A ( $27 \pm 3 \%$ vs. $27 \pm 3 \%, p=0.63)$. Strong correlations were detected in global ECV within the pairs of TWINS A and $\mathrm{B}$ (Pearson $\mathrm{R}=+0.70, \mathrm{p}=0.005$ ) and between the two measurements in TWINS A (Pearson $\mathrm{R}=+0.64, \mathrm{p}=0.015$ ). No significant difference was noted between Delta TWINS and Delta Variability $(0.8 \pm 2.5$ vs. $-0.4 \pm 2.7$, $\mathrm{p}=0.26)$.

\section{Conclusions}

ECV measurements in pairs of healthy monozygotic twins demonstrated similar global ECV values that did not vary more than the expected variability of measurement. Moreover, ECV measurements showed a very good reproducibility.

\section{Funding}

None.

${ }^{1}$ Cardiology, Uniklinikum Muenster, Muenster, Germany

Full list of author information is available at the end of the article 


\section{Authors' details}

${ }^{1}$ Cardiology, Uniklinikum Muenster, Muenster, Germany. ${ }^{2}$ Cardiology, Robert Bosch Hospital, Stuttgart, Germany. Institute for clinical pharmacology,

Stuttgart, Germany.

Published: 3 February 2015

doi:10.1186/1532-429X-17-S1-Q31

Cite this article as: Florian et al: Myocardial extracellular volume fraction (ECV) measurements based on T1-mapping in healthy monozygotic twins - another similarity or rather disagreement in twins? Journal of Cardiovascular Magnetic Resonance 2015 17(Suppl 1):Q31.

Submit your next manuscript to BioMed Central and take full advantage of:

- Convenient online submission

- Thorough peer review

- No space constraints or color figure charges

- Immediate publication on acceptance

- Inclusion in PubMed, CAS, Scopus and Google Scholar

- Research which is freely available for redistribution

Submit your manuscript at www.biomedcentral.com/submit
() Biomed Central 